\title{
Uses of macro social theory: A social housing case study
}

\author{
Chris Bevan* and Dave Cowan**
}

\begin{abstract}
This article reflects on the use of macro social theoretical perspectives to explain micro social issues. It uses social housing allocations as a case study of the issues that arise in such explanations. There has been a number of important social theoretical examinations of social housing allocation schemes in recent years, spanning socio-legal studies. In contrast to those other studies, we argue that "cookie-cutter" theory is insufficient because they can overlook other positions and counter-factual scenarios. We draw on a sample of local authority allocation schemes to reflect on the increasing category of excluded households which we term "unhouseables" (an expression which is commonly used by housing officers) - those households which are excluded from appearing on such schemes because of their former housing deviance or some other disqualification. We offer a set of reflections grounded in our data, which focus on sustainability. Thus, rather than point to particular rationalities or the like, we point to particular housing issues as explanatory factors - including the declining stock and financial "competitiveness" of social bousing management - as well as a rise in punitiveness.
\end{abstract}

Keywords: allocation; qualification; social housing; arrears; anti-social behaviour

\footnotetext{
* University of Nottingham

** University of Bristol
}

The authors are grateful to Simon Halliday, Tonia Novitz, Steven Greer, and the anonymous referees for helpful comments on an earlier draft. 


\section{Introduction}

Public services in England and Wales are in a state of flux. On $21^{\text {st }}$ July 2015, the Chancellor of the Exchequer, George Osborne, launched a spending review calling for further savings amounting to $f^{2} 2 \mathrm{bn}$ to be found from Whitehall budgets. Every unprotected government department is to begin modeling how they might cut budgets by 25 and 40 per cent by 2020 . Those savings are in addition to the $f 12 \mathrm{bn}$ of welfare savings already unveiled. Such cuts are likely to involve a reinvention in the very manner by which public services are delivered and enjoyed. On any assessment, public services are, across the board, entering yet another period of significant change and upheaval.

In this article, housing is the public service on which we focus, and more specifically the allocation of "social" housing (but, in truth, we could have selected other public services, from highways to prisons). Housing in particular has become a political hot topic, with each political party in the run up to the General Election in May pledging to outdo their rivals as to the number of houses they would build if elected, and with the Conservatives guaranteeing housing association tenants the right to buy their homes. It is now widely acknowledged, quite apart from party politicking, that there is an acute housing shortage, both private and social, and that previous measures designed to redress this shortage have failed.

Whilst the crisis within the housing sector is at present highly topical, challenges to the very nature of public services and their function are anything but new. Indeed, almost every change in government leads to apparently stark claims about the need for fundamental changes to the purpose of public services, which have extended beyond a simple question of who is to provide them. ${ }^{1}$ Specifically in the field of social housing, this has been shown to be too simplistic. ${ }^{2}$ The precise purpose or purposes behind social housing have remained largely undefined and unclear since its very inception. As Power pithily observed, 'Councils became landlords without commitment, plan or forethought.' ${ }^{3}$ This fevered context within which social housing operates and the contemporary public services 'cuts agenda' provides us in this paper with the impetus to consider not only how social housing is allocated by local authorities in this testing environment but also how social theory might be employed to explain this process.

\footnotetext{
${ }^{1}$ See, for example, P. Vincent-Jones, The New Public Contracting: Regulation, Responsiveness, Relationality (Oxford: OUP, 2006); C. Harlow \& R. Rawlings, Law and Administration (Cambridge, CUP, 2009), ch 2.

${ }^{2}$ See, for example, the discussion of purpose in S. Fitzpatrick and H. Pawson, "Welfare safety net or tenure of choice? The dilemma facing social housing policy in England", (2007) 22(2) Housing Studies 163; S. Fitzpatrick and H. Pawson, "Ending security of tenure for social renters: Transitioning to 'ambulance service' social housing?", (2014) 29(5) Housing Studies 597.

3 A. Power, Property before People: The Management of Twentieth Century Council Housing (London: Allen \& Unwin, 1987), 66.
} 
As to such theorizing, quite grand theoretical claims have been made. Thus, the Conservative Party's time in office in the 1980s has been described as entailing a shift in the provision of social housing from allocation on the basis of 'housing need' to being awarded according to who 'deserved' it. That shift was underscored by the Major Government with its ill-fated and illconceived "back to basics" philosophy, embodying a nostalgic appeal to so-called traditional values. ${ }^{4}$ By way of illustration, there was an explicit bias towards favouring married couples over cohabitants. ${ }^{5}$ The allocation of social housing in the New Labour era from 1997 has been defined as founded on "advanced liberalism", a link between a mentality of government and ethical self-regulation. ${ }^{6}$ The introduction of greater 'choice' into the system as a means of empowering communities during this time was portrayed as a solution to the principal housing problems. The Coalition Government's interventions have been identified with a number of new problematics including: whether the purpose of social housing was as a welfare safety net, an ambulance service; the site of further "class war conservatism"; 8 or the culmination of processes of the production of "welfare ghettos". "The Coalition focused its attention on the need for social housing to be governed from within, by and for the local; ${ }^{10}$ allocations were interpreted as "fundamentally a local" issue. ${ }^{11}$ Thus, the purpose of social housing was to respond to local need and the legislative prescription was, not surprisingly, also therefore local, encapsulated in the Localism Act 2011. ${ }^{12}$ This emphasis on localism and decentralisation continues under the current Conservative Government.

The central argument in this paper is that simple binaries, monochrome applications of social theories and perspectives, or even different strands of localism (with its lengthy and contested histories) cannot explain social housing allocation processes. In support of this argument, we

\footnotetext{
${ }^{4}$ See, for example, S. Fitzpatrick and M. Stephens, "Homelessness, need and desert in the allocation of council housing", (1999) 14(4) Housing Studies 413.

${ }^{5}$ See Department of the Environment, Allocation of Housing Accommodation and Homelessness (London: DoE, 1996), para 29.

${ }^{6}$ D. Cowan and A. Marsh, "From need to choice, welfarism to advanced liberalism: Problematics of social housing allocation”, (2005) 25(1) Legal Studies 22.

7 S. Fitzpatrick and H. Pawson, "Ending security of tenure for social renters: Transitioning to 'ambulance service' social housing?”, (2014) 29(5) Housing Studies 597.

${ }^{8}$ S. Hodkinson and G. Robbins, "The return of class war conservatism? Housing under the UK Coalition government" (2012) 33(1) Critical Social Policy 57.

9 L. Hancock and G. Mooney, "Welfare ghettos' and the 'broken society': Territorial stigmatization in the contemporary UK", (2013) 30(1) Housing, theory and Society 46, drawing in particular on L. Wacquant, Urban Outcasts: A Comparative Sociology of Advanced Marginality (Cambridge: Polity, 2008).

10 See, for example, C. Bevan, “The Localism Act 2011: The hollow housing law revolution”, (2014) 77(6) Modern

Law Review 964.

${ }^{11}$ CLG, Local Decisions: A Fairer Future for Social Housing, Consultation (London: CLG, 2010), 1.20.

12 Localism Act 2011. For contradictions and contestations in the Act's understandings of localism, see A. Layard, "Law and localism: The case of multiple occupancy housing", (2012) 32(4) Legal Studies 551. This was a policy which underpinned all the major parties policies at the 2015 election: See C. Wiles, “The housing election?", Inside Housing, 7th May 2015, http://www.insidehousing.co.uk/debate/expert-opinion/the-housing-election/7009632.blog (last accessed 2nd June 2015).
} 
advance three key findings. First, we draw on our own empirical evidence of a relatively neglected backwater to illustrate this point: those households which are excluded from social housing waiting lists or which, in the legislative vernacular, are "non-qualifying" households. From our survey of 50 Local Authority housing allocation schemes, we identify that each authority applies similarly-phrased but subtly distinct allocation qualification criteria.

Secondly, we build on the identification of this patchwork of qualifying criteria to reject what we call 'cookie-cutter' theoretical analysis. This leads us to call for the development of data-led social theories to explain social housing problems and processes. Our argument is that, although there is a temptation to adopt "a kind of cookie-cutter typification or explanation, a tendency to identify any program with neo-liberal elements as essentially neo-liberal", ${ }^{13}$ the strategies and techniques of government are far more complex and contradictory. No one size fits all, but, to continue the metaphor, there are different shapes of cookie-cutter apparently in action simultaneously, each with their own explanatory logics. ${ }^{14}$ As Larner observes, "[t]he emergence of new forms of political power does not simply involve the imposition of a new understanding on top of the old. The transformation of a polity involves the complex linking of various formats of practice, is ongoingly contested, and the result is not a foregone conclusion. Consequently, contemporary forms of rule are inevitably composite, plural and multi-form."15

Our point is that part of the problem with the "cookie cutter" approach is that it uses macro social theory to explain micro phenomena. The theoretical positions we review are best used on a very broad canvass of both time and space - in other words, they are best suited to describing large social trends; and it is always possible to dispute their use by drawing on micro data which do not "fit". We are not seeking to undermine or upset larger social theory but to argue for its more appropriate usage. Where it is used in relation to micro social processes, it can be used in an inappropriate way: first, to explain rather than describe, and, second, as an all-purpose starting point.

Our final and third finding, again from our data, is that the identified patchwork of housing qualification criteria carries with it the potential for the expansion of a category of households

\footnotetext{
${ }^{13}$ N. Rose, P. O’Malley and M. Valverde, "Governmentality", (2006) 2 Ann Rev Law Soc Sci 83, 97-8.

${ }^{14}$ Here, our "cookie cutter" analogy breaks down; Carr (personal correspondence) suggests that a jelly mould is better, but, whatever analogy is chosen, we must recognise its porousness and its fluid and malleable boundaries. Our approach has much in common with the theoretically peripatetic and nuanced appreciations in J. Newman, "Landscapes of antagonism: Local governance, neoliberalism and austerity", (2014) 51(15) Urban Studies 3290.

15 W. Larner, "Neo-liberalism: Policy, ideology, governmentality", (2000) 63 Studies in Political Economy 5.
} 
which are, in social housing parlance, 'the unhouseables'. ${ }^{16}$ This is not a category where housing deviance (a term we explain below) is to be neutralised through expulsion; nor are they households which, although now excluded, may be re-affiliated at a later time once they have demonstrated their self-governing capacities. ${ }^{17}$ They are, quite simply, banished by a "savage sorting" through an "ultimately elementary extraction", 18 and one that might be said to have its basis in the techniques of social science. ${ }^{19}$

As we explore, perhaps the most pertinent explanation is not the relatively broad-based grand theory, but one of transparent politics against a backdrop of coerced collaboration in which the more risky households are quite simply weeded out with no possibility (or, at least, no immediate possibility) of redemption. These are not conditionality strategies (which are well-documented aspects of social welfare ${ }^{20}$ ) through which the poor and supposedly indigent are exhorted to selfimprovement, ${ }^{21}$ but the punitive, sovereign strategy of having the door slammed in their faces. As we seek to explain, by whatever means one describes such strategies - as contradictory, as authoritarian liberalism, or naked and punitive sovereignty - they are neither politically nor spatially differentiated.

We begin this paper, however, by outlining the rather tortuous legislative and policy history surrounding social housing and, more specifically, by detailing the basis upon which households are excluded from such housing and how 'non-qualifying' status is determined.

\section{Social housing exclusions}

\section{The developing law: Rationales}

From the outset, exclusions were part and parcel of the social housing allocations process. ${ }^{22}$ Such exclusions were either implicit - the rent that was set was too high for many ${ }^{23}-$ or

\footnotetext{
16 This is a phrase which appears time and again across various empirical projects in which one of us has been involved. It refers to a category of household which no public or private agency wants to provide accommodation. They are not ready fodder for the private sector, as some of the more antagonistic, class theorists might suggest. ${ }^{17}$ As might be suggested by what Rose describes as "circuits of exclusion": N. Rose, "Government and control", (2000) 40 British Journal of Criminology 321, 330 et seq. 18 S. Sassen, Expulsions: Brutality and Complexity in the Global Economy (Cambridge, Mass: 2014), 4 and 15.

19 There is an overlap between our analysis and the insurantial moral hazard - both have in their sights the immoral person and the relationship itself "so as not to "lead us into temptation"”: T. Baker, "Insuring morality", (2000) 29(4) Economy and Society 559, 562.

${ }^{20}$ See, for example, M. Dean, “A genealogy of the government of poverty”, (1992) 21(3) Economy \& Society 215; W. Walters, Unemployment and Government (Cambridge: CUP, 2000).

${ }^{21}$ As are also current in social housing practices - see J. Flint, "Housing and ethopolitics: Constructing identities of active consumption and responsible community", (2003) 32(4) Economy and Society 611.

22 "The Ministry of Health provided guidance in 1920 which suggested "the careful selection of tenants" and "the elimination of unsatisfactory tenants", but did not offer any criteria under which such assessments could be made": D. Cowan and M. McDermont, Regulating Social Housing: Governing Decline (London: Routledge Glasshouse, 2006). ${ }^{23}$ M. Bowley, Housing and the State (London: Allen \& Unwin, 1945), 129.
} 
explicit. ${ }^{24}$ Early studies, for example, demonstrated how applicants were "graded" according to preconceived notions of deservingness, often occurring after the "housing visitor" (often, a middle aged, middle class female local government employee) came to discuss rehousing with the applicant(s). ${ }^{25}$ In 1993, 92 per cent of local authorities excluded certain households from their waiting lists. ${ }^{26}$ So, although it can properly be argued that the production of social housing was a means to manage the poor, it is also clear that only certain poor households were included in this process of what has been described as "moral cleansing". ${ }^{27}$

The Housing Act 1996, Part 6, formalised the social housing allocations process. Previously, legislation contained only vague reference to prioritisation through reasonable preference. ${ }^{28}$ The 1996 Act, for the first time, set out a requirement on local authorities to have a housing register and a published allocation scheme. ${ }^{29}$ Local authorities were given the power to "decide what classes of persons are, or are not, qualifying persons" and therefore to decide who was entitled to appear on the register (subject to statutory and quasi-statutory inclusions and exclusions). ${ }^{30}$ Certain persons from abroad were also made non-qualifying persons. ${ }^{31}$ The accompanying Code of Guidance, to which local authorities were required to refer, provided examples of the categories of households central government believed could be "non-qualifying":

people with a history of anti-social behaviour, people who have attacked housing department staff, or tenants with a record of rent arrears. Authorities could impose other qualifications, such as those related to residency in the authority's district or ownership of a property, although they may wish to consider the implications of excluding all members of such groups, eg elderly owneroccupiers. 32

\footnotetext{
${ }^{24}$ See, for example, the discussions in Central Housing Advisory Committee, Selection of Tenants and Transfers and Exchanges, $3^{\text {rd }}$ Report (London: HMSO, 1949); id, Council Housing Purposes, Procedures and Priorities, 9 ${ }^{\text {th }}$ Report (London: HMSO, 1969).

25 See, for example, Central Housing Advisory Committee, Council Housing: Purposes, Procedures and Priorities)London: HMSO, 1969); S. Damer and R. Madigan, R. "The housing investigator”, (1974) 25 July, New Society 226; J. Lambert, C. Paris and B. Blackaby, Housing Policy and the State: Allocation, Access and Control (Basingstoke: MacMillan, 1978). 26 W. Bines, P. Kemp, N. Pleace and C. Radley, Managing Social Housing (London: HMSO, 1993), para 9.28. The most commonly employed exclusions were where the household had other suitable alternatives; former tenants with rent arrears outstanding; and applicants below an age limit. Most providers also had a local connection requirement: paras 9.29-33. This suggested considerable continuity with the Central Housing Advisory Committee report findings from 1969.

${ }^{27}$ The early link between housing management and the Public Health department's interest in housing as a social practice sought "to systematise the surveillance, control and moralisation of the burgeoning working class": S.

Damer, "'Engineers of the human machine': The social practice of council housing management in Glasgow, 18951939”, (2000) 37(11) Urban Studies 2007.

28 The first provisions can be traced back to 1924, and were codified in the Housing Act 1985, Part II.

${ }^{29}$ S. 168.

${ }^{30}$ S. 161(4).

31 S. 161(1)-(3).

32 Department of the Environment, Allocation of Housing Accommodation and Homelessness (London: DoE, 1996), 4.27.
} 
It was $\operatorname{said}^{33}$ that the most common exclusion under that Act, as originally enacted, excluded those with rent arrears, without a "local connection" 34 with the authority, those guilty of antisocial behaviour, under $18 \mathrm{~s},{ }^{35}$ and owner-occupiers.

Despite a commitment to remove the qualifying persons provision in their 1997 election manifesto, it was not until the Homelessness Act 2002 that New Labour reversed it. The exclusion of households from abroad remained, but local authorities were prevented from making other households non-qualifying. There were good reasons for doing so, in line with the choice-based lettings (a market-based model of social housing allocation, requiring households to be active in their search by bidding for the property they wanted) ${ }^{36}$ and equalities agendas, as well as an ambition that lists would reflect housing need in the area. Further, it was in line with recommendations made by the then disbanded Central Housing Advisory Committee. ${ }^{37}$ However, this was not a completely altruistic policy, because it was also clear that the previous mantra of "allocation according to need" was also breaking down. As the 2000 Green Paper made clear: "We do not believe that social housing should only be allocated to the poorest and most vulnerable members of the community ... [W] recognise that there may be occasions when it is necessary and desirable, for some wider community benefit, to allow exceptions to this" ${ }^{38}$ The ability to exclude households from the list was replaced with a discretionary power to alter a household's priority as a result of behaviour which "affects his suitability to be a tenant", and financial resources. ${ }^{39}$ After the 2009 local elections, when the British National Party made some gains, albeit very limited, guidance was issued which suggested that local connection could be taken into account as a "policy priority" in allocations decisions. ${ }^{40}$

The Coalition government returned the original power to exclude to local authorities in the Localism Act 2011. The rationale was that "open waiting lists" had encouraged households to

\footnotetext{
${ }^{33}$ S. Butler, Access Denied: The Exclusion of People in Need from Social Housing (London: Shelter, 1998).

34 This phrase requires some explanation. It is widely used in housing circles, currently appearing in the homelessness legislation (Housing Act 1996, Part 7), but has its basis in early settlement rules under the Poor Laws see R. Cranston, Legal Foundations of the Welfare State (London: Weidenfeld \& Nicolson, 1978). It is usually taken to mean that, subject to certain limitations (eg in relation to those fleeing domestic violence), a household must have lived in an area for more than a set period. It has become an apparently accepted aspect of social housing allocations policy, one to which all signed up in 1996 (HL Debs, vol 573, cols 345-6), but see the trenchant critique of such policies in CHAC, 1969, ch 4.

35 This was a product of issues relating to the grant of a tenancy to under 18s, although other moral registers were also in operation: D. Cowan, Homelessness: The (In-)Appropriate Applicant (Aldershot: Dartmouth, 1997).

36 The system is discussed in A. Marsh et al, Piloting Choice-Based Lettings: An Evaluation, (London: ODPM, 2003).

${ }^{37}$ Selection of Tenants and Transfers and Exchanges, $3^{\text {rd }}$ Report (London: HMSO, 1949); id, Council Housing Purposes, Procedures and Priorities, $9^{\text {th }}$ Report (London: HMSO, 1969).

38 Department of the Environment, Transport and the Regions/Department of Social Security, Quality and Choice: $A$ Decent Home for All - The Housing Green Paper (London: DETR/DSS, 2000), para 9.12.

${ }^{39}$ S. 167(2A).

${ }^{40}$ CLG, Fair and Flexible, Statutory Guidance on Social Housing Allocations for Local Authorities in England, (London: CLG, 2010), 63.
} 
put their names down on the list where they had no real need for housing, and created "false expectations" in areas where demand outstripped supply. ${ }^{41}$ The guidance offered to local authorities about the new exclusion provision was rather more nuanced than that offered in 1996. It recognised that authorities had to balance their new power against their equalities obligations, the requirement to give reasonable preference to certain categories of household. There was also a more nuanced framing of exclusions and a suggestion that there should be an allowance for "exceptional circumstances"; and that they "should avoid setting criteria which disqualify groups of people whose members are likely to be accorded reasonable preference for social housing". ${ }^{42}$ Alongside this guidance, though, was a requirement by Statutory Instrument that local authorities could not apply local connection rules to certain members of the armed forces. $^{43}$

Subsequent guidance reinforced the government's view that local authorities "should prioritise applicants who can demonstrate a close association with the local area"; ${ }^{44}$ indeed, rather stronger than has appeared before in Statutory guidance. ${ }^{45}$ "The Secretary of State believes that including a residency requirement is appropriate and strongly encourages all housing authorities to adopt such an approach. The Secretary of State believes that a reasonable period of residency would be at least two years." ${ }^{46}$ This reflects an odd contradiction at the heart of social housing policy - the Coalition government (as those before it) emphasised the need for mobility, ${ }^{47}$ while at the same time prioritising local connection.

There is a clear tension in localism, however, between a coherent national scheme and local schemes. ${ }^{48}$ As Maclennan and O'Sullivan put it, "a commitment to localism in housing policy does not mean the abandonment of coherent housing policies and governance mechanisms at national, regional and metropolitan scales, and that a simple localisation of housing policy can dangerously hamper the development of effective, efficient and flexible housing systems" ${ }^{49}$ So,

\footnotetext{
${ }^{41}$ CLG, Local Decisions: A Fairer Future for Social Housing, Consultation (London: CLG, 2010), paras 4.5-6.

${ }^{42}$ CLG, Allocation of Accommodation: Guidance for Local Housing Authorities in England (London: CLG, 2012), 3.18-3.22.

43 Allocation of Housing (Qualification Criteria for Armed Forces) (England) Regulations 2012, SI 2012/1869.

${ }^{44}$ CLG, Providing Social Housing for Local People: Statutory Guidance on Social Housing Allocations for Local Authorities in England (London: CLG, 2013), 12.

45 Subject to the exception that "[i]t is important that housing authorities retain the flexibility to take proper account of special circumstances": 19.

46 Ibid, 13.

${ }^{47}$ CLG, Local Decisions: A Fairer Future for Social Housing, Consultation (London: CLG, 2010), section 5.

${ }^{48}$ See the interpretation of the Council Tax reduction scheme: R(Winder) v Sandwell MBC [2014] EWHC 2617 (Admin), [60], Hickinbottom J describing the scheme as "despite the principle of localism, to maintain a certain amount of consistency".

${ }^{49}$ D. Maclennan and A. O’Sullivan, "Localism, devolution and housing policies", (2013) 28(4) Housing Studies 599, 607; see also C. Hunter, "Localism, centralism and housing rights”, (2012) 15(1) Journal of Housing Law, 63, 65, who argues that that the Coalition government's version of localism was presented as "advantageous over 'inflexible
} 
a tension exists between local exclusions, regional allocation schemes, and national housing policy. If national housing policy is so vulnerable that households should be prioritised, ${ }^{50}$ then an exclusion makes no sense. Similarly, if a household is excluded by one local authority, a rational householder might be expected to seek out an alternative local authority not subject to such an exclusion Thus, the local pressure is likely to be to maintain qualification criteria at least similar, if not more strict, than your neighbour. There is the potential for a race to the bottom, although, as we shall see, that may not have occurred in practice.

The relevant provisions of the Localism Act 2011 were brought in to force in January 2012. By that stage, the size of local authority waiting lists had grown annually. By $1^{\text {st }}$ April 2012, there were 1,851,426 households on waiting lists in England. The most recently published statistics show that, as at $1^{\text {st }}$ April 2014, there has been a 26 per cent decrease in that number (there were 1,368,312 households on waiting lists in England). ${ }^{51}$ The bottom line is that nearly 500,000 households have apparently been wiped off waiting lists. It has been recognised by government that local authorities' "freedom to manage their own waiting list" is "probably partly responsible for this decrease". ${ }^{52}$ In that same year, 2013-14, there was a slight increase in the number of social housing general needs lettings (approximately 293,000 lettings were made). ${ }^{53}$ Internal transfers - which happen off register so to speak, as they are not now included on waiting lists ${ }^{54}$ - made up 23 per cent of all such lettings. ${ }^{55}$

\section{The judicial approach}

It is instructive to consider the interaction of the courts, local authorities and allocation schemes. As one commentator has observed, after a period in which social housing allocation schemes were subject to intense scrutiny, allocation schemes have been "de-judicialised" as a result of the

centrally-determined rules' but inflexible centrally determined rules can also be characterised as a national code of protective, justiciable rights".

50 As appears to be the case by reference to the categories of household to which reasonable preference must accrue on allocation schemes: s 166ZA, Housing Act 1996.

51 Table 600, Rents Lettings and tenancies: Numbers of Households on Local Authorities' Housing Waiting Lists, by District: England 1997-2014, https://www.gov.uk/government/statistical-data-sets/live-tables-on-rents-lettingsand-tenancies (last accessed, 19th May 2015).

52 DCLG, Local Authority Housing Statistics: Year Ending March 2014, Housing Statistical Release (London: DCLG, 2015), p. 6 (https://www.gov.uk/government/statistics/local-authority-housing-statistics-year-ending-march-2014, last accessed 19th May 2015).

53 Core data, table 1a, https://www.gov.uk/government/collections/rents-lettings-and-tenancies (last accessed, 19 th May 2015). "General needs" social lettings are those lettings, other than for supported housing, by local authorities and private registered providers. They include lettings at "social rent" (below market rent) and "affordable rent" (80 per cent of the market rent).

54 This was a further change made by the Localism Act 2011; the effect of competition between new lettings and transfers is discussed in D. Clapham and K. Kintrea, "Rationing, choice and constraint: The allocation of public housing in Glasgow", (1986) 15(1) Journal of Social Policy 51.

${ }_{55}$ Core data, table 2f, https:/ / www.gov.uk/government/collections/rents-lettings-and-tenancies (last accessed, $19^{\text {th }}$ May 2015). 
House of Lords decision in $\mathrm{R}\left(\right.$ Ahmad) $v$ Newham London Borough Council. ${ }^{56}$ The court refused to interfere with Newham's broad brush allocations scheme, which was based on date order (i.e. priority within broad bands was determined on the date on which applicants applied for accommodation). They did so because the statutory scheme gave authorities broad powers; and "it seems unlikely that the legislature can have intended that Judges should embark on the exercise of telling authorities how to decide on priorities as between applicants in need of rehousing, save in relatively rare and extreme circumstances. Housing allocation policy is a difficult exercise which requires not only social and political sensitivity and judgment, but also local expertise and knowledge". ${ }^{57}$

However, the court has shown itself to be more willing since implementation of the Localism Act 2011 to intervene to strike down perceived unfairness in the design and operation of allocation schemes. One such scheme, that of Hammersmith and Fulham LBC, warrants closer attention. Under this scheme, homeless households in long-term accommodation were excluded from appearing on their list, treated as non-qualifying households. At a stroke, this meant that 87 per cent of households were excluded. Homeless households are, however, statutorily accorded "reasonable preference" under the 1996 Act, as amended. ${ }^{58}$ The reasoning behind the exclusion was said to be that "the Council is recognising an obvious but often neglected truth i.e. that the housing needs of applicants owed the main housing duty are not uniform and that very often the quality of the accommodation provided in discharge of the main housing duty is such that the Council can reasonably conclude that an applicant's current housing needs are met". 59 The Court of Appeal struck this exclusion down. First, it was said that excluding entirely a proportion of households entitled to reasonable preference was outside the statutory scheme. ${ }^{60}$ An allocation "scheme" included not just those entitled to an allocation but also those excluded. This view was supported by the guidance (to which reference has been made above). Secondly, and perhaps less persuasively given the House of Lords' approach in Ahmed, the Court held that the exclusion of such a large proportion of applicants effectively thwarted the statutory scheme, despite the flexibility allowed to an authority in the term "reasonable preference". Tomlinson LJ doubted whether "either these proceedings have achieved any practical purpose or that the Claimant will derive any benefit from our decision" because it was observed that the

\footnotetext{
56 [2009] UKHL 14, [2009] 3 All ER 755.

57 [47].

58 S. $166 \mathrm{ZA}(3)$.

${ }^{59}$ R(Jakimaviciute) v Hammersmith and Fulham LBC [2014] EWCA Civ 1438.

${ }^{60}$ Cf R(Hilsden) v Epping Forest DC [2015] EWHC 98 (Admin), which is something of an outlier but in which a scheme requiring continuous residence for three years, without an exceptional circumstances clause, was upheld as lawful.
} 
council could simply adjust their allocation scheme so as to arrive at the same conclusion. ${ }^{61} \mathrm{~A}$ consideration of the judicial treatment of local authority allocation schemes provides one of the contexts in which our survey of 50 allocation schemes must be analysed. It is to this survey that we now turn.

\section{Local exclusions: Methodology}

In Summer 2014, we conducted an electronic survey of a selection of 50 local authorities' qualifying criteria, purposively sampled by reference to geographical area, political control, and whether rural/urban. The 'geographical area' element was selected on the basis of regional area, as used to be provided by the Department of Communities and Local Government in presentation of their statistics until 2011. ${ }^{62}$ 'Political control' and 'rural/urban' have both been indicated in past research to be relevant factors in analysing waiting lists. As authorities are required to publish their schemes, the focus on the actual allocations schemes meant that they were relatively easy to access online. ${ }^{63}$ We downloaded each of the published schemes and, for the purposes of this article, analysed their qualification criteria. As qualification criteria are more than "a matter of mere detail" (for example, because affected households can request a review of a negative decision), ${ }^{64}$ they are required to be included in the published allocations scheme. Thus, they appear on the face of the scheme. We coded them initially into four broad qualification criteria relating to (generalised) 'nuisance and anti-social behaviour', 'local connection', 'rent arrears', and 'other'. We used these categories because of the experience under the Housing Act 1996 as originally drafted, but, as we demonstrate below, the "other" criteria encompasses a range of more specific exclusions, some of which are used by a large proportion of our sample.

It is important to note that local authorities were sampled and not other providers of social housing (such as other social landlords). The reason for that limitation was because local authority allocation schemes tend to be the gateway to all social housing in an area, either because they operate "common housing registers" with other providers or because the authority has large proportion of nomination rights over other social housing in their area. ${ }^{65}$ One reason for this purposive sampling was that, although many local authorities were involved in regional

\footnotetext{
$61[52]$.

62 https://www.gov.uk/government/statistical-data-sets/live-tables-on-rents-lettings-and-tenancies, table 601 (last accessed $22^{\text {nd }}$ December 2014).

${ }^{63}$ S. 168(1). By way of methodological footnote, in a small number of cases, local authorities were unable to provide their scheme, either because it was being updated or it was not available. In such cases, we simply selected another authority in the same region.

${ }^{64}$ Lin v Barnet LBC [2007] EWCA Civ 132, [48], Dyson LJ.

${ }^{65}$ It is known that other providers can, and do, exclude nominees for their own reasons, but that is beside the point. If a household is excluded from the list, that is likely to be the end of the social housing process.
} 
schemes including in London, they tend to maintain their own non-qualification categories. It is realistic to suppose that different authorities in different regions, and perhaps within the same region, would have different categories if the "local" emphasis has purchase. It might also have been anticipated that a local connection emphasis would be more prevalent in rural areas, where there is a greater emphasis on maintaining locality in a limited housing stock. London, of course, is a different housing market altogether, as reflected in the Mayor's powers in relation to social housing construction, the extremely limited social housing stock, the high cost of living (such that restrictions on benefits cause particular problems), and the large-scale export of homeless households in out-of-area placements. However, one of the most interesting findings of this project is that the various factors that were taken in to account in our sampling did not appear to reflect exclusion policies.

There is a further and particular limit of our survey. We do not have the internal reports to the local authority committees which approved the new allocations schemes. Local authority data suggest that 60 per cent of local authorities have altered their allocation schemes since the Localism Act 2010. ${ }^{66}$ Each change would have been supported by an officer's report. Transparency applies only to the allocation scheme itself, which must be published. ${ }^{67}$ Therefore, we do not have the local authority perspective for the changes. There is no particular proxy that can be used either - for example, local authorities are required to produce a homelessness strategy and a tenancy strategy (and, for London, its own housing strategy), ${ }^{68}$ but these documents do not provide the basis for alterations.

\section{Local exclusions: Outcomes}

We analysed our sample of allocation schemes by reference to four particular categories, drawing on the experiences under the 1996 Act as first settled, the current guidance, and newspaper reports of exclusions as they were appearing. ${ }^{69}$ These sources suggested the likely prevalence of three categories of non-qualifying households: those with rent arrears, without a local connection, and nuisance/anti-social behaviour. An "other" category was also maintained to account for other types of exclusion. The manner in which local authorities constructed their non-qualifying categories beyond these broad labels was also of interest to us - for example, the measure of rent arrears giving rise to exclusion from allocation schemes. If local connection was

\footnotetext{
${ }^{66}$ Local Authority Housing Statistics, 2013-4, Table C: https://www.gov.uk/government/statistical-data-sets/localauthority-housing-statistics-data-returns-for-2013-to-2014 (last accessed, 19th May 2015).

${ }^{67}$ S. 168, Housing Act 1996.

${ }^{68}$ Respectively s. 1, Homelessness Act 2002; s. 150, Localism Act 2011. Local authorities in England must have regard to such documents in producing their allocations scheme: s. 166A(12), Housing Act 1996.

${ }^{69}$ H. Spurr, "Locked out", Inside Housing 2 ${ }^{\text {nd }}$ May 2014.
} 
a category, how long does a household have to have an association with the area? And, if antisocial behaviour, what type and what proof was required?

\section{General}

Every local authority surveyed had some form of qualification criterion. Beyond that, the general results of our survey were that, as regards the specific, named exclusions:

- 44 authorities had qualification criteria for nuisance or anti-social behaviour, 3 authorities had no such exclusion, and for 3 others it went to prioritisation (i.e. an applicant's prioritisation on the list could be reduced because of such behaviour).

- 27 local authorities had qualification criteria for local connection, 3 had no such exclusion, and for 20 others it went to prioritisation.

- 30 local authorities had qualification criteria for rent arrears, 8 did not, and for 12 others it went to prioritisation.

Where an authority was coded as not having a relevant named qualification criterion, that does not necessarily mean that there was no sanction. So, for example, West Berkshire DC did not "exclude" an applicant for rent arrears but "defers" their application. ${ }^{70}$ Similarly, the London Borough of Enfield did not "exclude" an applicant for rent arrears but "suspends" the application. ${ }^{71}$ Sheffield City Council's modus in respect of anti-social behaviour was to retain discretion either to "suspend [a household's] registration" or "otherwise restrict it". Effectively, even where there was no qualification criterion, de-prioritisation and "suspension" or "deferment" may well amount to the same thing (particularly in high demand areas). ${ }^{72}$

Much of this is not surprising. What is surprising, however, is the low number of local authorities which had an explicit qualification criterion for local connection. Given the emphasis on the "local" in the Localism Act 2011, there was an assumption that this would be the most significant qualification criterion of qualifying status (and it had been a prominent exclusion under the 1996 Act as originally settled). It nevertheless turned out to be a far less prominent criterion in our sampled schemes than anticipated. Indeed, the same is true for past rent arrears. The significant number of local authorities with an explicit nuisance/anti-social behaviour

\footnotetext{
${ }^{70}$ Before the deferment will be lifted, applicants need to demonstrate that they have made and adhered to an agreed payment plan for a period of at least three months and/or that the arrears have been cleared or have been reduced below eight weeks rent.

${ }^{71}$ Applicants with more than eight times the weekly accommodation charge or have not maintained a payment agreement for six months will have application suspended until arrears repaid or payment plan maintained for six months.

72 And it is notable that most (but not all) such formulations were in high demand areas.
} 
qualification criterion can be explained by the increasing attention given to tackling anti-social behaviour by policy-makers and its depiction as a social housing problem reaching back as early as the 1990 s. $^{73}$

As to the category of 'other' qualification criteria, Table 1 below indicates the range and frequency of particular criteria:

Table 1: "Other" Exclusions

\begin{tabular}{|l|l|}
\hline Exclusion & $\begin{array}{l}\text { Number of local } \\
\text { authorities }\end{array}$ \\
\hline $\begin{array}{l}\text { Making false or misleading } \\
\text { statements to obtain a } \\
\text { tenancy }\end{array}$ & 29 \\
\hline Owning own home & 26 \\
\hline $\begin{array}{l}\text { Income and/or capital } \\
\text { threshold limits }\end{array}$ & 22 \\
\hline $\begin{array}{l}\text { Previous eviction on a } \\
\text { Housing Act ground }\end{array}$ & 11 \\
\hline $\begin{array}{l}\text { Causing Damage or waste to } \\
\text { property }\end{array}$ & 8 \\
\hline $\begin{array}{l}\text { Deliberately worsening } \\
\text { personal circumstances }\end{array}$ & 6 \\
\hline Any other criminal offence & 5 \\
\hline $\begin{array}{l}\text { Previous acts of domestic } \\
\text { violence and/or racist abuse } \\
\text { and/or harassment }\end{array}$ & 3 \\
\hline High risk household & 2 \\
\hline
\end{tabular}

In addition, households with high care needs, refusing an offer of accommodation, squatters, and poor tenancy report were excluded by one local authority each. There are clear overlaps with nuisance/anti-social behaviour as regards some of these criteria and others are either high profile housing issues (such as making a false or misleading statement to obtain a social housing tenancy), covered by strong guidance, ${ }^{74}$ or are high profile housing allocation issues (such as the

\footnotetext{
${ }^{73}$ See, for example, J. Flint, "Social housing agencies and the governance of anti-social behaviour", (2002) 17(4) Housing Studies 619; K. Jacobs, J. Kemeny and T. Manzi, "Power, discursive space and institutional practices in the construction of housing problems", (2003) 18(4) Housing Studies 429; A. Brown, "Anti-Social behaviour, crime control and social control", (2004) 43(2) Howard Journal of Criminal Justice 203.

74 So, for example, the Allocations Code makes a strong statement regarding home owners: "The Government believes that authorities should avoid allocating social housing to people who already own their own homes": para 3.23 .
} 
income and/or capital restriction ${ }^{75}$ ). Even the more apparently contentious qualification criteria, such as an unsatisfactory tenancy report (Durham CC), have a history in social housing allocation which would not overly surprise a housing academic or professional. ${ }^{76}$

Specifics

It is to be noted that, as regards each of the named exclusions, the policies use similar, almost generic formulations (although the specifics are rather different, as discussed below). It is not surprising because, as Spicker noted, there were similarities in allocations policies in the 1980s because practitioners shared views with each other and drew on government Guidance; further, "[m]any housing departments face similar pressures, and they respond with similar policies as a result". 77

Perhaps the most significant underlying reason for this similarity in phrasing and scheme formulation is legislative and quasi-legislative framing of the qualification. So, for example, as regards nuisance/anti-social behaviour, the most common formulation was: "An applicant (or a member of their household) found to have engaged in unacceptable behaviour serious enough for the landlord to pursue court action had they been a tenant" - or unacceptable behaviour that was serious enough for a court to order possession $(n=39)$ - a formulation of unacceptable behaviour that was previously found in section 160(8) of the Housing Act 1996, prior to the Localism Act amendments. ${ }^{78}$ Similarly, the general definition of "local connection" was tied to that provided in the homelessness legislation and the local authority agreed protocol. ${ }^{79}$ Although less frequent, a common formulation for rent arrears was the equivalent of a Housing Act 1985 or 1988 ground for possession "rent lawfully due that has not been paid (current or former tenancy)". 80

Once the analysis becomes more fine-grained, however, distinctions and considerable scope for discretion emerge. So, for example, on rent arrears, a common expression of the qualification criterion was "significant rent arrears". Some local authorities were explicit as to what this meant - the range was from two weeks arrears (Northampton) to 14 weeks, the median being eight weeks ( $\mathrm{n}=4$; including three local authorities in the South West). Where a precise figure was stated, the most common figure used was $£ 1,000(\mathrm{n}=5)$. However, 17 local authorities provided

\footnotetext{
75 DCLG, High Income Social Tenants: Pay to Stay, Consultation (London: DCLG, 2012).

76 This was the sort of practice favoured by Octavia Hill's followers, and which was common practice until the late $1970 \mathrm{~s}$

77 P. Spicker, “Concepts of need in housing allocation", (1987) 15(1) Policy and Politics 17, 24.

78 This provision still applies in Wales: s. $160 \mathrm{~A}(8)$.

79 S. 199; Procedure for Referrals of Homeless Applications on the Grounds of Local Connection with another Local Authority, reproduced as Annex 18, Homelessness Code of Guidance for Local Authorities (London: DCLG, 2006), para 4.1.

${ }^{80}$ Grounds 1 and 10 respectively.
} 
no definition of significant rent arrears (although some reduced prioritisation for low or moderate $\left.\operatorname{arrears}^{81}\right)$. Only East Riding of Yorkshire DC in our sample expressed a clear limitation period as regards rent arrears - two years. The same is true of nuisance/anti-social behaviour, although here most local authorities provided the generic descriptor followed by lists of relevant conduct. ${ }^{82}$ Where authorities excluded applicants above a threshold of behaviour, many would also give less priority to applicants who made it on to the list but with arrears or behaviour below the threshold.

Similar observations can be made in relation to local connection. 14 local authorities, in fact, departed from the local authority protocol when it came to the specific periods of residence in the locality. The range of these periods was from six months to 10 years (Hillingdon LBC), with one local authority (Kingston-upon-Thames RLBC) providing no specific period. The median specific period was three years $(n=4)$. All London boroughs (other than Kingston) surveyed had a specific period of residence required, ranging from two years (Havering LBC) to 10 years. Ealing and Greenwich had 5 year requirements; Hackney a 3 year requirement; Newham a 2 year requirement; City of London a 12 month requirement. ${ }^{83}$ The range here was surprising, in part because of the move to a pan-London allocations scheme and the conflict with regional consistency. Whether or not such lengthier periods survive must be open to some doubt and are likely to be susceptible to challenge. ${ }^{84}$

In relation to rent arrears and nuisance/anti-social behaviour (although less so in relation to the latter), some local authorities offered some degree of redemption. In all such cases, the onus is clearly on the applicant to demonstrate some behavioural change. As regards rent arrears, where the applicant entered in to a re-payment plan, 20 local authorities across our entire sample either took this in to account in deciding on qualification, prioritisation, or “postponement/suspension”. At a more detailed level, however, a number of authorities either required the applicant to have been meeting the relevant payments regularly for (say) six months (Stevenage, Hackney, and Hillingdon). For others in our sample, the degree of commitment to repayment of arrears was merely a relevant factor to be taken into account either to bolster or

\footnotetext{
${ }^{81}$ Except Middlesbrough MBC which specifically included low to moderate arrears as "unacceptable behaviour". 82 The following were included as examples: ASBO granted $(n=7)$; criminal proceedings had been successfully instigated (17); dogs (1); domestic violence/racists abuse and/or harassment (15); eviction for breach of tenancy obligation (10); history of anti-social behaviour (9); use of a property for immoral or illegal purposes (11); noise (1); property neglect or damage (9); abuse of staff (7); acts of violence (2).

${ }^{83}$ City of London is the smallest London borough for these purposes.

${ }^{84}$ In $\mathrm{R}$ (Winder) $v$ Sandwell MBC, Hickinbottom J accepted the ground of challenge to that authority's council tax reduction scheme, which had a local connection element, on the basis that it constituted a barrier to freedom of movement and was indirectly discriminatory in EU law: [80]-[90]; see also the discussion of Barnet LBC's consultation on changes to its allocation scheme: http://nearlylegal.co.uk/blog/2014/08/waiting-wait/ (last accessed 29th December 2014).
} 
weaken an individual's case. So, for example, Preston BC express their qualification criterion in part as where the applicant has a housing related debt up to $£ 1,000$ and has not made a repayment plan which has been maintained in accordance with the policy; however, an applicant will qualify if the re-payment plan has been maintained for a minimum of 3 months for debts of up to $\AA^{500 \text {. }}$

5 local authorities across our sample offer "redemption" to those who might otherwise have been excluded for nuisance/anti-social behaviour. The usual requirement was that the applicant has changed their behaviour for a certain period. Northumberland DC, for example, may exercise its discretion in favour of qualification where there is evidence of the applicant's improved behaviour over a sustained period of time; Hillingdon LBC, which does not exclude but "verifies" applicants, will not so verify an applicant unless they can demonstrate a change in their behaviour for a minimum of 12 months at the time of an allocation.

\section{Qualification and social theory}

In this section, we are concerned with the ways in which social theory has been, or might be, deployed to explain social housing allocations. We draw attention to four particular explanations: a form of advanced liberalism; actuarialism and risk; class war Conservatism; and authoritarian liberalism. Our argument is that our data disrupts such neat theoretical explanations, and we should be led by our data rather than resort to the cookie cutter.

Some qualification criteria have the ethical self at their heart - what we have termed 'redemption'. They fit neatly in to post-Foucauldian governmentality studies which focus on advanced or neo-liberal political rationalities exhorting people to work on themselves. They promise to remove the stain of disqualification if the applicant improves themselves (such as, for example, making and keeping an arrangement to pay back rent arrears). Applicants can break the "circuit of exclusion" to which they have been marked. However, that explanation is rather too simple because, for some, that stain cannot be removed whatever action the applicant takes. Local connection is neither liberal, nor neo-liberal nor advanced liberal as a political rationality. There is no apparent purpose to the exercise of the exclusionary power in this case because it does not affect an individual's self-government. ${ }^{85}$

\footnotetext{
85 A similar set of arguments can be deployed against the revival in housing studies of Bourdieu's notion of the bureaucratic field, as developed by Wacquant, op cit $\mathrm{n}$ 7; also in K. Jacobs and T. Manzi, "Investigating the new landscapes of welfare: Housing policy, politics and the emerging research agenda", (2014) 31(2) Housing, Theory and Society 213, 220-1.
} 
Perhaps an actuarial approach, with which criminal justice scholars are familiar, ${ }^{86}$ offers a rather better explanation. As Dean puts it, risk "is a way of representing events in a certain form so they might be made governable in particular ways, with particular techniques and for particular goals" ${ }^{87}$ Cowan, Pantazis and Gilroy have considered the way social housing allocation embeds risk-based assessment and management within its processes. They claim that, in social housing selection processes "risk has always been the central principle; this has simply become more apparent in recent years. Selection processes have been designed to assess the risks posed by particular individuals both to the management of social housing as well as to the safety of the community. If a person is regarded as 'risky', they are likely to be excluded from social housing or allocated stock which nobody else wants". ${ }^{88}$ That claim was made in the context of a study of the rehousing of sex offenders, in a situation in which the risk management of the offender clearly imbued the entire allocation process.

One can see the calculability of risk in relation to some of the exclusions. So, for example, rent arrears are a risk to a social housing organisation, whose business plan will be predicated on the collection of a particular proportion of rent as its income. The exclusion of a bad payer is a fairly crude risk management device; the re-inclusion of those applicants who have kept to a repayment plan can properly be described as a more fine-tuned risk assessment process. The management of nuisance/anti-social behaviour is financially and emotionally costly to social housing organisations and, thus, the exclusion of those households is readily explicable in the language of risk. However, risk does not provide a general explanation for the complete array of exclusions. It cannot explain local connection. Indeed, the argument made was that social housing provides spaces and places in which the risky can be controlled, whereas our focus here is on the excluded, rather than the punitive containment of households on estates. ${ }^{89}$ Thus, our argument departs from the assertion that risk has always been the central principle defining social housing selection.

Drawing on Ralph Miliband's description of the Thatcher government as exercising "class war conservatism", some have argued that Coalition government housing policy was largely completing the job. Hodkinson and Robbins argue that " $[\mathrm{h}]$ ousing policy is being used as a strategic intervention to unblock and expand the market, complete the residualisation of social housing and draw people into an ever more economically precarious housing experience in order

\footnotetext{
${ }^{86}$ M. Feeley and J. Simon, "The new penology. Notes on the emerging strategy of corrections and its implications", (1992) 30(4) Criminology 449; also P. O’Malley's sophisticated take on the agonism the heart of penology: "Volatile and contradictory punishment" (1999) 3(2) Theoretical Criminology 175.

${ }^{87}$ M. Dean, Governmentality: Power and Rule in Modern Society (London: Sage, 1999), 177.

88 D. Cowan, R. Gilroy and C. Pantazis, "Risking housing need", (1999) 26(4) Journal of Law and Society 403, 406.

${ }^{89} \mathrm{We}$ are here drawing on Wacquant, op cit $\mathrm{n} 7$.
} 
to boost capitalist interests". ${ }^{90}$ On this view, the expanding category of unhouseables provides fodder for an ever more ravenous private rented sector or owner-occupation, which are being fed also on a diet of occupiers' welfare benefits. Thus, the stigmatisation of social housing as providing "ghettos" for the "welfare poor" is part of a discursive formation in which capital is benefiting. However, the empirical evidence does not support this proposition either - private landlords are risk averse, unlikely to provide housing to those in receipt of welfare benefits, and mortgage lenders unlikely to enter such risky markets because of the stringent entry rules postcrash. ${ }^{91}$ There is also the point that the qualification criteria predate Thatcher, and the roots of local connection can be found in the local settlement provisions of the Poor Laws. ${ }^{92}$

It appears therefore that what we are left with is that no one approach fits all the qualification criteria. A range of potential explanations - path-dependency, institutionalism (in the sense that institutions are enduring collections of rules, structures and standard procedures), and various formats of neo-liberalism - co-exist. The shadow of the past is lengthy. ${ }^{93}$ Local connection forms a qualification criterion because of its pertinent history from settlement under the Poor Law on, its spatial defence against "outsiders", and its reinvigoration as a criterion as a result of a certain form of nationalism. ${ }^{94}$

To refer to the qualification criteria as "neo-liberal" requires some further explanation. After all, these criteria are punitive sanctions and, as discussed above, only certain of the authorities surveyed allowed for individuals to 'redeem' themselves and qualify under a scheme. Scholars of neo-liberal governmentality have recognised the authoritarianism inherent within it. Dean, for example, argues that "authoritarian foldings" arise as a result of the joining up of state organisations and civil society, such as the tenant participation movement, the enfolding of civil society processes into the political sphere, and the refolding of the values of civil society into the political sphere. The important point to note here is that civil society norms are translated into a set of norms enforceable, if necessary, by sovereign action. ${ }^{95}$ This has the benefit of reinforcing what is often forgotten in governmentality studies, and that is that Foucault himself emphasised the triangle of sovereignty-discipline-government, not the displacement of one by the other.

\footnotetext{
${ }^{90}$ Op cit n 96, 59.

${ }^{91}$ See generally, D. Cowan, Housing Law and Policy (Cambridge: CUP, 2011).

92 See R. Cranston, Legal Foundations of the Welfare State (London: Weidenfeld and Nicolson, 1985), pp 22-6.

93 Although it should be said that, even in 1949, the Central Housing Advisory Committee recognised that "A [person's] need for a house is not affected by local authority boundaries or by the length of time [s/he] has lived or worked within them"; and recommended that such conditions be abolished "as soon as conditions permit": Selection of Tenants and Transfers and Exchanges, 3 ${ }^{\text {rd }}$ Report (London: HMSO, 1949), para 13. The 1969 report was "... firmly of the conviction that there should be no barrier to acceptance on a housing list": para 169.

94 op cit $\mathrm{n} 84$.

95 M. Dean, "Liberal government and authoritarianism", (2002) 31(1) Economy and Society 37, 45-6.
} 
Indeed, as he put it, the problem of sovereignty is made more acute than ever by advances in the theory of government. And, as Valverde argued, illiberal practices of moral governance are "a seldom noticed but irreducible despotism in the heart of the paradigmatic liberal subject's relation to himself". ${ }^{96}$ Dean and Valverde both recognise this as key to appreciating the remoralisation strategies of conditionality in welfare. ${ }^{97}$

However, even with such more nuanced appreciation of the term "neo-liberal", the explanation remains problematic. We now turn to explanations from within housing policy itself.

\section{Qualification criteria and housing policy}

In this section, we are concerned with the interaction between qualification criteria and housing policy. We consider how they fit with explanations of housing allocations that place housing need, desert, and sustainability at their forefront. Our contention in this paper is that these qualification criteria have produced a new, expanded generation of "unhouseables". The greater ability (and apparent willingness) of local government to disqualify more applicants through local exclusions together with the increasing numbers of excluded households are evidence of this strain. These are households who are labelled as having some type of former housing deviance they are the "outsiders": "deviance is not a quality of the act the person commits, but rather a consequence of the application by others of rules and sanctions to an 'offender'. The deviant is one to whom that label has been successfully applied; deviant behavior is behavior that people so label". ${ }^{98}$ The significant number of households excluded from social housing lists reflect the increasing number of outsiders, ${ }^{99}$ to a certain extent caught in the anomic trap. These are the predominantly risky households and others who can be lumped together.

Exclusions are not purely to do with housing "need" - indeed, those with rent arrears and past histories of anti-social behaviour are likely to have greater need for social housing because of their inability to access other housing tenures. Fitzpatrick and Stephens make a case that "when it is said that housing should be allocated to those in most need, what is really meant is that it should be allocated to those who are in greatest housing deprivation", and deprivation should be considered over the long-term. ${ }^{100}$ However, the qualification criteria clearly operate as blunt tools independent of housing need.

\footnotetext{
${ }^{96}$ M. Valverde, “'Despotism' and ethical liberal governance”, (1996) 25(3) Economy and Society 357, 359.

${ }^{97}$ See N. Rose, Powers of Freedom: Reframing Political Thought (Cambridge: Polity, 1999); W. Walters, Unemployment and Government (Cambridge: CUP, 2000).

${ }^{98}$ H. Becker, The Outsiders (New York: Free Press, 1973), 9.

${ }^{99} \mathrm{Op}$ cit $\mathrm{n}$ 52-4.

100 Op cit n 3, 420
} 
There is an argument that the qualification criteria reflect desert, something which has been particularly prevalent in social housing allocation schemes since their foundation. ${ }^{101}$ The justification for desert in allocation schemes is that social housing "consumption provides utility not only to those who are housed, but also to those who provide it ('society')". ${ }^{102}$ If one interprets desert in the manner of "moral rectitude", ${ }^{103}$ one can see that central government's prescription that armed service personnel are automatically qualifying as a clear example of desert, ${ }^{104}$ but local connection provisions stand in defiance of desert.

Another way of analysing the qualification criteria which is less pejorative is through the label now current in social housing of the need for "sustainability". Sustainability has a personal, estate, and global implication for social housing. The personal effect is that tenancies should be sustainable, and considerable management effort goes in to that purpose. An estate effect is that estates should be sustainable, meaning that they should not be allowed to "slip", for example as a result of the actions of a "bad apple" or a consequence of an unfixed "broken window". As significant are the increasing concerns about a nebulous category of "outsiders", often regarded as persons from abroad, occupying estates so that family members of households already living on the estate cannot be housed there. ${ }^{105}$

The implication is that social housing has come to be seen as a residualised tenure - a numerically declining tenure with concentrations of poverty: "the poverty of existing social tenants is almost certainly a contributory factor in the unattractiveness of the sector for betteroff groups". ${ }^{106}$ Social housing and its occupants are stigmatised "as particular locales where social pathologies and problems flourish". ${ }^{107}$ In order to destigmatise it, it is necessary to exclude some households so that the positive role models required can be housed - itself redolent of the 1938 Central Housing Advisory Committee report which advocated "The bad tenant will learn more readily by eye than by ear: example is better than precept". ${ }^{108}$ Sustainability implies

\footnotetext{
101 A point discussed in detail in D. Cowan and M. McDermont, Regulating Social Housing: Governing Decline, (London: Routledge Glasshouse, 2006), ch 4.

102 Fitzpatrick \& Stephens, op cit n 3, 427.

103 A phrase used by the Cullingworth committee: CHAC, Council Housing, Purposes and Priorities, $9^{\text {th }}$ Report (London: HMSO, 1969), 33.

${ }^{104}$ DCLG, Laying the Foundations: A Housing Strategy for England (London: DCLG, 2011), 52; for critique, see S. Hodkinson and G. Robbins, "The return of class war conservatism? Housing under the UK Coalition government" (2012) 33(1) Critical Social Policy 57, 69.

105 This is another powerful myth: D. Robinson, "New immigrants and migrants in social housing in Britain: Discursive themes and lived realities", (2010) 38(1) Policy and Politics 57.

${ }^{106}$ S. Fitzpatrick and H. Pawson, "Welfare safety net or tenure of choice? The dilemma facing social housing policy in England", (2007) 22(2) Housing Studies 163, 177.

${ }^{107}$ L. Hancock and G. Mooney, "Welfare ghettos' and the 'broken society': Territorial stigmatization in the contemporary UK", (2013) 30(1) Housing, Theory and Society 46, 48.

108 CHAC, 1938, 20.
} 
conditionality: the purpose of social housing is now linked with broader welfare policy, ${ }^{109}$ something which has become current since the mid-1990s and led to the fin de siècle academic debate about the "end of housing policy". ${ }^{110}$ Never mind that the data does not support the assertions of ghettos with patterns of worklessness and benefit dependency, ${ }^{111}$ nor the powerful role of the state in the production of "advanced marginality" ${ }^{112}$ amid the austerity trope. ${ }^{113}$

The sustainability narrative is certainly powerful but also contradictory. If social housing is "ambulance service" housing, so that access is only granted to those with severe vulnerabilities, ${ }^{114}$ then the stigma will be hard to shift. However, despite its inherent contradictions, this narrative provides an underpinning that reflects the backdrop to this new set of problematisations about social housing. To put it another way, exclusions can be seen as a response to the decline in housing finance. The management of social housing has been consistently squeezed since the mid-1970s through central government cuts and other processes, ${ }^{115}$ such as bidding for loans which reward those with lower management costs. ${ }^{116}$ The other major factor here is the numerical decline in housing stock - there is now less social housing stock than private rented stock for the first time since the 1960s, and the increased tentacles of the right to buy under the Coalition government continued to reduce the stock (the same policy is also to be found in the Conservative manifesto for this government). ${ }^{117}$ The basic problem with transparent choicebased allocation schemes which reflect housing need in an area is that they accentuate expectations when those expectations patently cannot be met. ${ }^{118}$ As Henderson and Karn observed in their classic study of institutional discrimination in Birmingham's allocation scheme

\footnotetext{
109 See, for example, Work and Pensions Select Committee, Benefit Sanctions beyond the Oakley Review, $5^{\text {th }}$ Report, $18^{\text {th }}$ March 2015.

110 This debate was led by P. Malpass, "Housing policy: Does it have a future?”, (1999) 27(2) Policy and Politics 217.

111 D. Robinson, "Social housing in England: Testing the logics of reform", (2013) 50(8) Urban Studies 1489.

112 L. Wacquant, Punishing the Poor: A Comparative Sociology of Advanced Marginality (Cambridge: Polity, 2008); Hancock \& Mooney, op cit $\mathrm{n} 101$.

${ }^{113}$ K. Jacobs and T. Manzi, "New localism, old retrenchment: the 'big society', housing policy and the politics of welfare reform", (2013) 30(1) Housing, Theory and Society 29.

114 Fitzpatrick \& Stephens, op cit $\mathrm{n} 3$.

115 On the distorting effects of the Local Government and Finance Act 1989 regime, see P. Malpass, M. Warburton, G. Bramley and G. Smart, Housing Policy in Action: The New Financial Regime for Council Housing (Bristol: School for Advanced Urban Studies, 1989).

116 This lead to various entrepreneurial developments in management, as to which see, for example, R. Walker, "The changing management of social housing: the impact of externalisation and managerialisation", (2000) 15(2) Housing Studies 281.

117 The Conservative Party Manifesto (London: Conservative Party, 2015), pp 51-2, proposed the right for housing association tenants to buy their homes on the same basis as local authority occupiers, with local authorities selling off their more expensive stock to fund the discounts.

118 This was accepted by the Coalition government as the rationale behind the qualification regime: "The requirement to maintain open waiting lists, coupled with the introduction of choice-based lettings, may also have encouraged a commonly held - but mistaken - perception that anyone will be able to get into social housing if they wait long enough": DCLG, Local Decisions: A fairer Future for Social Housing (London: DCLG, 2010), para 4.6; cf C. Bevan, "The Localism Act 2011: The hollow housing law revolution", (2014) 77(6) Modern Law Review 964.
} 
in the 1970s, "[w] hat emerges most forcefully from this study is that the management of public sector housing cannot be separated from its production. Only in the production of more suitable types of housing for families and for the elderly and single, and in the constant up grading of existing housing can many allocation problems be brought within manageable limits". ${ }^{119}$ This is what frames social housing now as "transitional" and "ambulance service" - terms which amount to the same thing, namely temporary housing - and also underpins the need for this ever-greater category of unhouseables.

This understanding of sustainability as the guiding rationality ties in with Loic Wacquant's development of Bourdieu's notion of the "bureaucratic field". ${ }^{120}$ As befits one of Bourdieu's students and collaborators, ${ }^{121}$ Wacquant's conclusions are broad, stark and critical. ${ }^{122}$ He argues that social and penal policy should not be isolated from each other because they "function in tandem at the bottom of the structure of classes and places". ${ }^{123}$ He begins with a treatise on social in/security, neo-Darwinism, and penality, which results partly in the "most disruptive elements" being "neutralize[d] and warehouse[d]". ${ }^{124}$ What for our purposes is significant about this argument is that, like Bourdieu, Wacquant is rigorously empirical. It is this which enables him, for example, to differentiate the specificities of urban marginality in the US and France. ${ }^{125}$

It is this methodological proposition that we advocate, ${ }^{126}$ one which links method with institutional analysis, and to which we return in our conclusion. Theory is derived from our data but not completely abstracted from "the macrostructural determinants that, although ostensibly absent from the neighbourhood, still govern the practices and representations of its residents because they are inscribed in the material distribution of resources and social possibles as well as lodged inside bodies in the form of categories of perception, appreciation and action." ${ }^{\text {"27 }}$ If this is the

\footnotetext{
119 J. Henderson and V. Karn, Race, Class and State Housing: Inequality and the Allocation of Public Housing in Britain (Aldershot: Gower, 1987), 277.

${ }^{120}$ He explains this most clearly in L. Wacquant, "Crafting the neoliberal state: Workfare, prisonfare and social insecurity", (2010) 25(2) Sociological Forum 197; P. Bourdieu, "Rethinking the state: On the genesis and structure of the bureaucratic field", (1994) 12(1) Sociological Theory 1; id, The Social Structures of the Economy, Cambridge: Polity, 2005. ${ }^{121}$ See, for example, P. Bourdieu and L. Wacquant, An Invitation to Reflexive Sociology (Oxford: Polity, 1992).

122 Wacquant is particularly withering about “... a certain magazine sociology that shamelessly lumps together schoolyard brawls, stairwell graffiti, and riots in derelict housing projects, in accordance with the demands of the new political common sense": Punishing the Poor: The Neoliberal Government of Social Insecurity (Durham: Duke UP, 2009), p. 2.

${ }^{123} \mathrm{Id}, \mathrm{p} .13$. He argues that "... the fight against street delinquency now serves as screen and counterpart to the new social question, namely, the generalization of insecure wage work and its impact on the territories and life strategies of the urban proletariat."

${ }^{124} I d$, p. 7.

125 Urban Outcasts: A Comparative Sociology of Advanced Marginality, (Cambridge: Polity, 2008).

126 Although, we should add, we are not specifically advocating a Bourdieusian methodology, but empirical and analytical rigour.

127 Urban Outcasts: A Comparative Sociology of Advanced Marginality (Cambridge: Polity, 2009), p. 10; for discussion of the representations of social housing residents, see K. Jacobs, J. Kemeny and T. Manzi, "Power, discursive space and
} 
case, then, of course, our conclusions from the data are likely to be different and equally subjective. ${ }^{128}$

Thus, sustainability operates as a link between what Wacquant describes as the tension between the left hand and right hand of the state - between the social ministries of state responsible for housing and welfare, and the enforcing state, with its economic discipline, resort to punitiveness, and judicial enforcement. ${ }^{129}$ It may be the case that what we now have are segregated spaces of "advanced marginality", ${ }^{130}$ in which community bonds are disintegrating, where stigmatisation and marginalisation are rife, and which operate discursively as framing the "broken society". 131 But, and this is distinctive about our data, rather than concentrating poverty in degraded spaces, social housing qualification criteria provide a crude mechanism to redress and distort those problems. Local connection provisions reinforce community bonds, enabling management to govern more efficiently. Rent arrears and nuisance/anti-social behaviour exclusions destigmatise and offer the social housing in an area an opportunity for redemption in its own right.

However, what Wacquant emphasises is the crucial role of the state and capital in the production of such spaces and, indeed, the response. ${ }^{132}$ The right hand of the state, through the effects of austerity policies and other economic practices (such as the whittling away of social housing subsidies), has produced this current situation, which others are implementing. That is not to say that those others are coerced (expressly or impliedly) into developing these criteria - precisely the reverse. Indeed, the local state's engagement of these criteria is significant, probably not as an explicit response to advanced marginality but to local and national politics. It should be remembered that all of our sample local authorities had qualification criteria of one kind or other.

What is clear is that the onus is on the applicant household to prove that they are not unhouseable. They must have a clean housing record. And, just as in the old days, what the schemes analysed reinforce is the role of discretionary judgment by housing officers. ${ }^{133}$

institutional practices in the construction of housing problems", (2003) 18(4) Housing Studies 429; D. Cowan, Homelessness: The (In-)Appropriate Applicant, (Aldershot: Dartmouth, 1997).

128 See A. Sarat, "Off to meet the wizard: Beyond validity and reliability in the search for a post-empiricist sociology of law", (1990) 15(1) Law and Social Inquiry 155.

129 The latter is particularly evident in Punishing the Poor: The Neoliberal Government of Social Insecurity (Durham: Duke UP, 2009).

${ }^{130}$ Urban Outcasts.

${ }^{131}$ See, for discussion, L. Hancock and G. Mooney, "Welfare ghettos' and the 'broken society': Territorial stigmatization in the contemporary UK", (2013) 30(1) Housing, theory and Society 46.

132 His understanding of neo-liberalism is inherently sociological, as opposed to the governmentality scholars - on which, see Larner, op cit $\mathrm{n} 13$.

133 This at a time when local authority budgets are facing further cuts and the consequent constraints to funding for training and recruitment of housing officers. The Guardian Newspaper has reported the mounting challenges faced 
Definitions of "serious" rent arrears or "unacceptable behaviour" are left open. In this sense, we have returned to the 1970s when "discretion was depicted as the bug in the system - a source of deviance which allowed short-term management goals to compromise the principle of social justice. It was the smokescreen behind which housing departments infused an agreed hierarchy of needs with a range of other, more dubious, allocative principles". ${ }^{134}$ It was this kind of behaviour which drew such considerable criticism from both left and right in the 1980s. ${ }^{135}$

\section{Conclusion}

Social housing's purpose has always been unclear. It was not part of the post-World War II welfare settlement, and, originally, it was too expensive for the poor. ${ }^{136}$ It is easily manipulated as a result. There has always been a category of "unhouseables" and the extent of that category is likely to have varied according to spatial factors and local/national political economy. Drawing on a textual analysis of the qualification criteria of 50 local authority housing allocation schemes, our argument is that a process of net-widening and mesh-thinning has occurred, which has facilitated a growth in the number of households excluded from social housing - a hiving off of a sub-set of "the dispersed and disparate populations caught in the pincer of social and spatial marginalization". 137

As we have identified, previous explorations of social housing allocation schemes have left us illequipped to conceptualise this process. Schemes which emphasise local connection provide the most significant challenge to those explanations. Other challenges come from sanctions which punish what we have termed housing deviance, particularly when schemes appear to offer no chance of redemption.

On one view, the fairly simple response is that the growth of this category of unhouseables is due to endogenous factors - a decline in the social housing stock and in the ability of social housing management to manage the stock due to financial constraints. However, many other factors are in play: the bureaucratic rule in which the social agencies rub up against the penal

\footnotetext{
by housing officers becoming ever more concerned with debt collection and the provision of financial advice: B. Reeve-Lewis, 'How has welfare reform changed the role of housing officer?' The Guardian (London, 13 May 2013) $<$ http://www.theguardian.com/housing-network/2013/may/13/welfare-reform-changed-housing-officer-job > last accessed 21 January 2015.

${ }^{134}$ S. Smith and S. Mallinson, "The problem with social housing: Discretion, accountability and the welfare ideal", (1996) 24(3) Policy and Politics 339, 341.

${ }_{135}$ See, for discussion, I. Cole and R. Furbey, The Eclipse of Council Housing, London: Routledge, 1994.

${ }^{136}$ For a fuller account see P. Malpass Housing and the Welfare State: The development of Housing Policy in Britain (Palgrave Macmillan, 2005).

137 Urban Outcasts, p. 245.
} 
complex; the willingness by some to allow for redemption, provided the applicant demonstrably changes their behaviour; a return of discretionary judgment for which social housing allocation was criticised in the latter part of the twentieth century as a result of the increase of discretion; and the vain politics of the government's good news that they have reduced the size of waiting lists, thus reducing housing need by the fairly simple rewriting of the rules. ${ }^{138}$ In this way, it becomes possible to argue that recent incarnations of localism should be viewed as endowing local government with greater flexibility in the management of their housing stock rather than benefiting would-be social tenants. ${ }^{139}$

As we have argued through the analysis of 50 local authority social housing allocation schemes, no single theoretical position provides a complete explanation - each provides a partial view on certain aspects. Wacquant's observations come closest, but that is most likely because they are grounded in data, as ours are. What is different about Wacquant's analysis from our own is his focus on spatial segregation of the urban marginalia as an outcome of policies and practices in his analysis - whereas, in our study, the ultimate housing outcome of the "unhouseables" is neither known nor inscribed, beyond the label of "private renting” or 'homeless'.

Our argument is that a 'cookie-cutter' approach to social theory fails to offer a meaningful and satisfactory explanation of social housing problems. What we are advocating, however, is an attentiveness to method. ${ }^{140}$ Our call is for the development of social theories that are grounded in data. Cookie-cutter explanations that begin from a particular theoretical perspective do not provide much assistance because they are not designed to provide such explanations. They are themselves contextualised and embedded. They may provide us with structural and analytical tools but slavish adaptations and translations to different empirical instances is itself problematic. In part, this reflects the unique and contextually specific features of experiments in neoliberalism, and the enfolding of new and old ideas. ${ }^{141}$ If socio-legal studies tell us anything, it is that the shadow of the past remains, albeit mobile with time, so that a more sociological approach, attendant to specificities and counter-factual scenarios, provides an important corrective.

\footnotetext{
138 See, for example, Grant Shapps, the then housing Minister, "Reforms will lead to first cut in waiting lists for 22 years", https://www.gov.uk/government/news/reforms-will-lead-to-first-cut-in-waiting-lists-for-22-years (last accessed 27th July 2015).

${ }^{139}$ See C. Bevan, “The Localism Act 2011: The hollow housing law revolution”, (2014) 77(6) Modern Law Review 964. 140 As Wacquant observes, ethnographic observation emerges as an essential tool but always combined with institutional analysis: Urban Outcasts, pp. 9-11.

${ }^{141}$ See J. Peck, Constructions of Neo-Liberal Reason (Oxford: OUP, 2012), who notes further "Certainly, there is no neoliberal replicating machine. Rather, each experiment should be seen as a form of reconstruction, representing a conjunctural episode or movement in the contradictory evolution of neoliberal practice" (original emphasis).
} 
The corollary of our analysis is that synchronic and comparative static institutionalist analyses which provide a bare, partial picture - should be rejected in favour of a diachronic approach. A diachronic analysis concerns itself with the development and change of a subject over time akin to a 'historical' construction, whereas a synchronic analysis is confined to analysis of particular snapshot in time. Diachronic analyses provide - certainly in this context - a more complicated picture through which continuities and discontinuities can be traced over time. ${ }^{142}$ Wacquant makes this move in his study of urban poverty, arguing that singular events (such as riots) can only be viewed diachronically: "to forget that urban space is a historical and political construction in the strong sense of the term is to risk (mis)taking for 'neighbourhood effects' what is nothing more than the spatial retranslation of economic and social differences". ${ }^{143}$ Thus, time itself becomes an important object of study, one which is often left out of socio-legal analysis, as an important adjunct of, for example, space. ${ }^{144}$ And time here is not thought about as linear, but as plural and complex, so that it is mashed up. ${ }^{145}$ In our study, we find layers of uneven shapes like the rings in a tree reflecting particular weather conditions, or uneven substrata - which demonstrate the formalisations of different common sense interventions at different moments, all of which coagulate into current housing allocation schemes. ${ }^{146}$

Our final point is that political processes have been subordinated to an understanding of housing "crisis", which constructs the lack of affordable social housing as requiring such interventions as have increased the numbers of "unhouseables" in the name of localism. The "good news" story central government can now tell, about declining housing need because, as an apparent indicator of housing need, housing waiting lists are getting shorter. This dominant narrative is being met with alternative, subaltern processes of resistance. One of the lessons of housing politics in 2014 was of increasing grassroots housing activism, combined with a disconnect between politicians and the electorate. ${ }^{147}$

Law has provided one significant method of challenging the adoption of these criteria. It represents one of the remaining mechanisms through which authoritarian interventions can be challenged in the housing sphere. Law's power remains visible. Instinctively, this feels rather

\footnotetext{
142 See C. Hay, Political Analysis, (Basingstoke: Palgrave, 2002), p. 149.

143 Urban Outcasts, p. 9.

${ }^{144}$ See, for example, Mariana Valverde's plea for legal geographers to take temporality seriously: "'Time thickens, takes on flesh': Spatiotemporal dynamics in law", in N. Blomley and I. Braverman (eds), The Expanding Spaces of Law, (Chicago: Stanford UP, 2014); also M. Valverde, Chronotopes of Law: Jurisdiction, Scale and Governance, (London: Routledge, 2015).

${ }^{145} \mathrm{Id}$.

146 As suggested by L. Bennett and A. Layard, "Legal Geography: Becoming spatial detectives”, (2015) 9(7) Geography Compass 406, 417-8.

${ }^{147}$ J. Birch, “10 things about 2014”, Inside Housing, 1 January 2015.
} 
odd and problematic because the judicial review process provides a method through which individuals can challenge a decision made on behalf of the collective, after consultation, in the allocation of scarce resources. ${ }^{148}$ However, law appears to be a significant mechanism for change - despite the existence of groups struggling against bureaucracies in high pressure areas, agitating for change and squatting empty properties (which are ironically evicted by the proper application of law). ${ }^{149}$ Further, the developing jurisprudence on this crucial issue of allocations does not speak with one voice and is, perhaps paradoxically, attendant to the local. ${ }^{150}$

We have already noted the potential issues with local connection as a policy and the striking down of Hammersmith and Fulham LBC's allocation scheme, which sought to exclude homeless households. There must now be a very real prospect of a cascading effect of nervousness amongst other local authority housing teams following that decision. ${ }^{151}$ Given our findings, that sense of nervousness is likely to be pretty much universal. Some long-cherished and/or overlaid assumptions appear to be challengeable. Building on the Hammersmith experience, there must be some doubt as to at least some of the other qualification criteria if it means that households to which the authority is required to give reasonable preference are excluded.

\footnotetext{
148 This was a central reason for the decision in Abmad, see for example Baroness Hale, at [11]-[13] - further, as Lord Neuberger put it, “...the yawning chasm between the supply of social housing, and the demand for it from such a large number of households with pressing needs, [means that] any scheme for allocating Newham's housing could be criticised" [54].

149 These groups are discussed in D. Cowan and S. Wheeler, "The reach of human rights", in J. Alian and T. Qu (eds), Property and Human Rights (Oxford: Hart, forthcoming).

${ }_{150}$ Compare the Hammersmith and Epping Forest decisions.

${ }^{151}$ In gathering the data for this study, routinely local authorities reported their allocations policies to be under close review in view of the changing legal landscape.
} 